\title{
INFLUÊNCIA DO PODER ECONÔMICO E FINANCIAMENTO PÚBLICO DE CAMPANHAS ELEITORAIS ${ }^{1}$
}

Pedro Roberto Decomain ${ }^{2}$

\section{Vedação constitucional da influência do poder econômico nas eleições}

No Direito Eleitoral brasileiro existem causas de inelegibilidade previstas na própria Constituição. Acham-se consignadas nos $\S \S 2^{\circ}, 4^{\circ}, 5^{\circ}$, $6^{\circ}, 7^{\circ}$ e $8^{\circ}$ do art. 14 da Constituição.

De acordo com o $\S 2^{\circ}$ desse artigo da Constituição, "não podem alistar-se como eleitores os estrangeiros e, durante o período do serviço militar obrigatório, os conscritos". Já o seu $\S 4^{\circ}$ afirma serem inelegíveis os inalistáveis e os analfabetos. Dessa sorte, é inelegível o conscrito, assim como o é também o estrangeiro. Quanto a este, deve-se salientar ainda que sua candidatura a mandato eletivo restaria inviável também por não atender à condição de elegibilidade representada pela nacionalidade brasileira, nos termos do art. $14, \S 3^{\circ}$, inciso I, também da Constituição. Além disso, inelegíveis são também os analfabetos.

O $\S 5^{\circ}$ do art. 14 da Constituição não trata propriamente de inelegibilidade, muito embora nele também haja a previsão de algumas. De acordo com aquele parágrafo, o Presidente da República, os Governadores dos Estados e do Distrito Federal e os Prefeitos Municipais, assim como quem os houver sucedido ou substituído no curso dos mandatos, poderão ser reeleitos para um único período subsequente. Significa isso a proibição de uma segunda reeleição (para um terceiro mandato sucessivo), o que importa em inelegibilidade dos chefes do Poder Executivo para esse terceiro mandato imediatamente subsequente.

Por meio do $\S 6^{\circ}$ de seu art. 14, a Constituição exige que o Presidente da República, os Governadores de Estados e do Distrito Federal e os Prefeitos Municipais renunciem aos seus cargos pelo menos seis meses antes da data prevista para as eleições, caso desejem concorrer a mandatos eletivos distintos daqueles que ocupam. Vale dizer que, caso persistam no exercício da chefia do Executivo dentro dos seis meses imediatamente anteriores à data da eleição, tornam-se inelegíveis para qualquer outro cargo. 
Já o $\S 7^{\circ}$ considera inelegíveis, para qualquer mandato eletivo da respectiva circunscrição eleitoral, os cônjuges e parentes - por consanguinidade ou afinidade, inclusive por adoção, até o segundo grau dos chefes de Poder Executivo e daqueles que os hajam substituído nos seis meses imediatamente anteriores à data prevista para as eleições, salvo se o cônjuge ou parente já for detentor de mandato eletivo e for candidato à reeleição.

Finalmente, o § $8^{\circ}$, ainda uma vez do art. 14 da Constituição, afirma serem elegíveis os militares alistáveis (o que afasta a elegibilidade somente dos conscritos durante o tempo em que prestam o serviço militar obrigatório), desde que preencham uma dentre duas condições, conforme o tempo que se encontrem em serviço ativo.

De acordo com o inciso I desse parágrafo, tratando-se de militar com menos de dez anos de serviço ativo, deve deixar definitivamente o serviço (ao menos até a data do pedido de registro de sua candidatura, segundo nosso entender) e, já agora conforme o seu inciso II, tratando-se de militar com dez ou mais anos de serviço ativo, deve agregar-se à autoridade superior, até a data do pedido de registro da candidatura, assim permanecendo até a data da eleição (o dispositivo refere-se a militar com mais de dez anos de serviço ativo, mas merece ser interpretado no sentido de referir-se aos que contem dez ou mais, sob pena de restar carente de qualquer normatização a situação do militar que, na data do pedido de registro de sua candidatura, contar exatamente dez anos de serviço ativo, nem mais, nem menos).

A par da previsão dessas causas de inelegibilidade, a Constituição, todavia, ainda afirma, no § $9^{\circ}$ do seu art. 14, que, mediante lei complementar, podem ser previstas outras causas de inelegibilidade, além daquelas inseridas no próprio texto constitucional.

A lei complementar que dispuser a respeito de outras causas de inelegibilidade deve prever também o respectivo prazo de cessação, o que exclui a possibilidade da previsão de causas de inelegibilidade vitalícias. Finalmente, sempre de acordo com o $\S 9^{\circ}$ do art. 14 da Constituição, as causas de inelegibilidade previstas em lei complementar devem ser hábeis a proteger: 1) a probidade administrativa; ou 2) a moralidade para o exercício do mandato, considerada a vida pregressa do candidato; ou 3) a normalidade e a legitimidade das eleições contra a influência do poder econômico ou o abuso do exercício de função, cargo ou emprego na administração direta ou indireta. Dessa sorte, causa de inelegibilidade infraconstitucional (porque prevista em lei complementar, e não no próprio 
texto constitucional) que não se preste efetivamente a proteger algum desses valores, padecerá de inconstitucionalidade substancial.

O que releva salientar neste ponto, porque de interesse para o tema discutido, é a inclusão, pelo texto do parágrafo em apreço, da normalidade e legitimidade das eleições em face da influência do poder econômico, como valor a ser protegido pela previsão de novas causas de inelegibilidade mediante lei complementar.

\section{0 significado da palavra "influência" no § $9^{\circ}$ do art. 14 da Cons- tituição: o uso e o abuso do poder econômico nas eleições}

Esse tópico constitucional, no atinente à vedação da influência do poder econômico como possível fator de desequilíbrio no resultado das eleições, merece a interpretação mais ampla possível, já que dele não se haverá de extrair unicamente fundamento para a previsão de eventuais novas causas de inelegibilidade, mas também uma outra consequência: não tolerar a Constituição Federal a influência do poder econômico nos resultados dos pleitos eleitorais. Em outras palavras, considera esses resultados conspurcados em sua legitimidade, quando possam haver decorrido dessa influência. Como se deve entender, todavia, a expressão influência do poder econômico?

É bem verdade que a Lei Complementar n. 64/1990, que hoje veicula as demais causas de inelegibilidade conhecidas no Direito Eleitoral brasileiro - além daquelas previstas pela própria Constituição, em seu art. $1^{\circ}$, inciso I, alínea "d" -, com a redação que Ihe foi conferida pela Lei Complementar n. 135, de 2010, que passou a ser conhecida como "Lei da Ficha Limpa", afirma a inelegibilidade dos que "tenham contra sua pessoa representação julgada procedente pela Justiça Eleitoral, em decisão transitada em julgado ou proferida por órgão colegiado, em processo de apuração de abuso do poder econômico ou político, para a eleição na qual concorrem ou tenham sido diplomados, bem como para as que se realizarem nos 8 (oito) anos seguintes". Seria, porém, a influência do poder econômico, a que se refere o texto constitucional, o mesmo que abuso do poder econômico, na dicção do texto da lei complementar?

Veja-se o comentário de Manoel Gonçalves Ferreira Filho ao aludido § $9^{\circ}$ do art. 14 da Constituição:

Influência do poder econômico. O uso da riqueza para objetivos político-eleitorais é condenado pelo texto em estudo. Note-se que, no dispositivo em vigor, ao contrário do estabelecido no direito anterior, 
não é só o abuso do poder econômico que deve ser reprimido. Também o seu uso, ou seja, a sua influência há de ser coibida. Por isso, a lei deverá tornar inelegíveis todos aqueles que possam prevalecerse da riqueza para influir nos pleitos eleitorais, e não apenas excluir os que dela abusaram. ${ }^{3}$

Efetivamente, a Constituição de 1967, até a Emenda Constitucional n. 1, de 17 de outubro de 1969, em seu art. 148, inciso III, fazia referência a que lei complementar pudesse prever outras causas de inelegibilidade, além das já então consignadas no próprio texto constitucional, desde que por meio dessa previsão se pudesse assegurar, entre outros valores, a "normalidade e legitimidade das eleições, contra o abuso do poder econômico e do exercício dos cargos ou funções públicas". ${ }^{4}$

Com a Emenda Constitucional n. 1/1969, ${ }^{5}$ persistiu a possibilidade de que lei complementar previsse outras causas de inelegibilidade, além daquelas versadas no próprio texto constitucional, para preservação, porém, da normalidade e legitimidade das eleições não mais apenas em face do abuso do poder econômico, mas já agora da sua influência. A redação do dispositivo era a seguinte:

Art. 151. Lei complementar estabelecerá os casos de inelegibilidade e os prazos dentro dos quais cessará esta, visando a preservar:

$[\ldots]$

III - a normalidade e legitimidade das eleições contra influência ou o abuso do exercício de função, cargo ou emprego públicos da administração direta ou indireta, ou do poder econômico; [...]. ${ }^{6}$

Aquele dispositivo da Emenda Constitucional n. 1/1969 mereceu de Manoel Gonçalves Ferreira Filho o mesmo comentário por ele feito ao § $9^{\circ}$ do art. 14 da atual Constituição. ${ }^{7}$

Não existe a menor razão para que se discorde desse pensamento. Acredita-se, todavia, que o dispositivo comentado possa sofrer interpretação ainda mais ampla.

A situação já não será unicamente de afastar-se do pleito, pela previsão de sua inelegibilidade, aquele que poderia prevalecer-se de sua riqueza e do poder que esta Ihe possa trazer, empregando a primeira e exercendo o segundo de modo abusivo para influir nos pleitos eleitorais. Certamente que tal providência é salutar, tanto que levou à previsão dos prazos de desincompatibilização previstos pelo art. $1^{\circ}$, II, alíneas "e", "f" e "h", da Lei Complementar n. 64/1990. ${ }^{8}$ 
Na medida em que o $\S 9^{\circ}$ do art. 14 da Constituição permitiu que lei complementar erigisse à categoria de causas de inelegibilidade fatos que pudessem conspurcar a normalidade e legitimidade das eleições em face da influência do poder econômico, deve tal parágrafo ser interpretado de maneira abrangente.

O que ele contém sem dúvida alguma é mensagem de que, além de proscrever o abuso do poder econômico, chega a proscrever o seu uso, como mecanismo capaz de influir na vontade do eleitorado, produzindo com isso distorções e, principalmente, acarretando desigualdades insuperáveis entre os que são e os que não são detentores de poder econômico.

Para que tal conclusão fique mais clara, basta que se faça a distinção entre influência do poder econômico - expressão utilizada pelo § $9^{\circ}$ do art. 14 da Constituição - e abuso.

Influência significa interferência ou, ao menos, possibilidade de interferência de um determinado fenômeno em outro. Há influência de um fenômeno sobre outro quando o primeiro interfere, em maior ou menor extensão, na produção do segundo. A palavra influência, aqui, como se verifica, tem conotação que se aproxima da expressão "nexo de causalidade". Influir é interferir, podendo produzir um determinado fenômeno ou podendo modificá-lo.

Dessa perspectiva, a influência do poder econômico nas eleições estará instalada sempre que, ao menos potencialmente, pelo uso desse poder se possa modificar o resultado das eleições.

Já a palavra abuso tem conotação bastante distinta.

Com precisão, Pedro Henrique Távora Niess resumiu isso: "Nada há de errado com o poder, desde que não interfira na liberdade, respeitando o Direito. Abusar do poder é ir além do permitido."

Já tivemos ocasião de dizer o mesmo, porém empregando mais palavras:

O abuso do poder econômico, cuja ocorrência justifica a inelegibilidade, é o emprego de recursos produtivos (bens e serviços de empresas particulares, ou recursos próprios do candidato que seja mais abastado), fora da moldura para tanto traçada pelas regras de financiamento de campanha constantes da Lei n. 9.504/1997, com o objetivo de propiciar a eleição de determinado candidato. ${ }^{10}$ 
Na mesma senda caminha Joel José Cândido:

O "uso" do poder é lícito e em nenhum momento é vedado pela legislação. Basta, tão só, que ele seja exercido com observância da lei e por quem possa exercê-lo, ou seja, o eleitor, as pessoas jurídicas, os partidos, coligações e os candidatos. O ilegal é o "abuso" de poder que se caracteriza pelo excesso ou demasia com que esse poder (seja econômico, político ou de autoridade) é exercido, buscando benefícios eleitorais, deturpando o processo eleitoral e influindo em seus resultados naturais. ${ }^{11}$

Nas palavras de Orlando Vaz:

O abuso do poder econômico pode ser entendido, e deve ser comprovado, como o excesso de gastos no processo eleitoral, através do qual o candidato pode conquistar o mandato eletivo. É evidente que os gastos declarados pelo partido político, controlados e legalmente admitidos pela Justiça Eleitoral, não constituem abuso. Este se caracteriza pelo mau uso, ou uso errado, excessivo ou injusto, como na própria definição etimológica do termo. Para que fique caracterizado o abuso, o candidato fará prevalecer a gastança exorbitante e descomedida, incidente pela utilização do poder econômico excessivo. ${ }^{12}$

Também Antônio Carlos Mendes assim se expressa:

A noção de "abuso" traduz comportamento contrário ao direito ou ao que excede os limites e finalidades consagradas pela ordem jurídica. Nesse sentido, fala-se em "abuso de direito" quando alguém exercita um direito, mas em aberta contradição, seja com o fim (econômico) a que esse direito se encontra adstrito, seja com o condicionamento ético-jurídico (boa-fé, bons costumes, etc.).

Com efeito, a doutrina utiliza-se da expressão "abuso do poder" para significar o uso abusivo ou o uso do poder para além da medida legal, excesso ou desvio de poder, uso arbitrário ou ilícito do poder. ${ }^{13}$

A observação é perfeita: o abuso é o uso para além do permitido.

Como conclusão, pode-se afirmar que o abuso do poder econômico consiste no seu uso - é dizer, no emprego desse poder - para além do permitido.

Outra conclusão evidente salta, então, aos olhos: se o abuso do poder econômico nas eleições significa o seu uso para além do permitido, então se tem por permitido o uso do poder econômico nas eleições, desde que mantido dentro da moldura legal traçada. 
Essa possibilidade do uso do poder econômico nas eleições advém particularmente do financiamento privado das campanhas eleitorais.

Como é bem sabido, as fontes básicas de financiamento das campanhas eleitorais são os recursos dos próprios partidos, especialmente aqueles oriundos do Fundo Partidário, previsto no art. 38 da Lei n. 9.096/ 1995, Lei dos Partidos Políticos, e, em muito maior monta, recursos provenientes de doações de pessoas físicas ou de pessoas jurídicas e recursos próprios do candidato.

As duas primeiras, dentre essas fontes privadas de custeio das campanhas eleitorais, são disciplinadas pela Lei n. 9.504/1997, conhecida como Lei das Eleições. As doações de pessoas jurídicas também eram permitidas pela mesma lei, através de seu art. 81. O dispositivo, todavia, teve sua inconstitucionalidade reconhecida pelo Supremo Tribunal Federal na Ação Direta de Inconstitucionalidade n. 4.650. Além disso, restou revogado pela Lei n. 13.165, de 29 de setembro de 2015, que trouxe número significativo de modificações à Lei das Eleições (e também à Lei dos Partidos Políticos).

Em seu art. 23, a Lei n. 9.504/1997 disciplina as doações de pessoas físicas para campanhas eleitorais, afirmando, no $\S 1^{\circ}$ desse artigo, também com redação nos termos da Lei n. 13.165/2015, não poderem elas exceder, por doador, quantia equivalente a $10 \%$ de seus rendimentos brutos auferidos no ano anterior ao da eleição. Já no parágrafo $1^{\circ}$-A, de seu art. 23, a lei também autoriza os candidatos a utilizarem recursos próprios no custeio de suas campanhas eleitorais, afirmando que estes não poderão exceder o limite máximo de gastos com a candidatura, estabelecidos na própria Lei n. 9.504/1997. Aduza-se que o § 1º-A de seu art. 23 foi acrescentado pela Lei n. 13.165, de 2015.

A propósito dos limites máximos de gastos de campanhas eleitorais, o art. 17-A da Lei n. 9.504/1997, a ela acrescido pela Lei n. 11.300, de 10 de maio de 2006, assim dispunha:

Art. 17-A. A cada eleição caberá à lei, observadas as peculiaridades locais, fixar até o dia 10 de junho de cada ano eleitoral o limite dos gastos de campanha para os cargos em disputa; não sendo editada lei até a data estabelecida, caberá a cada partido político fixar o limite de gastos, comunicando à Justiça Eleitoral, que dará a essas informações ampla publicidade.

Já o art. 18 da Lei das Eleições, igualmente acrescentado pela Lei n. 11.300/2006, assim dispunha: 
Art. 18. No pedido de registro de seus candidatos, os partidos e coligações comunicarão aos respectivos Tribunais Eleitorais os valores máximos de gastos que farão por cargo eletivo em cada eleição a que concorrerem, observados os limites estabelecidos nos termos do art. 17-A desta Lei.

O art. 18 teve sua redação modificada pela Lei n. 13.165/2015, passando a ter agora o seguinte conteúdo: "Art. 18. Os limites de gastos de campanha, em cada eleição, são os definidos pelo Tribunal Superior Eleitoral com base nos parâmetros definidos em lei."

Finalmente, o art. 17-A foi revogado expressamente pela Lei n. 13.165/ 2015.

Assim, o contexto que se tem, no tocante ao limite máximo de gastos de campanha, é o de que estes devem ser fixados pelo TSE, atendendo, porém, aos parâmetros definidos em lei, nos termos da atual redação de seu art. 18. Dificuldade certamente surgirá, se não vier a ser editada lei fixando tais parâmetros. Cabe acrescentar que não constam da própria Lei das Eleições. O TSE não dispõe de autonomia para a fixação dos limites máximos de gastos. Sua função será apenas a de calculá-los e divulgá-los, fiscalizando a Justiça Eleitoral o seu cumprimento, mas de acordo com os parâmetros que venham a ser legalmente fixados. Em não os havendo, limite algum em verdade existirá.

Cabe acrescentar que até o momento inexiste, entre nós, norma jurídica que defina limite máximo de gastos com as candidaturas a mandatos eletivos. O máximo que tínhamos eram as disposições dos arts. 17A e 18 da Lei n. 9.504/1997, já anteriormente transcritas; a primeira delas revogada e a segunda com seu conteúdo amplamente modificado.

Por fim, no art. 81, essa lei autorizava as doações de campanha efetuadas por pessoas jurídicas, estabelecendo-lhes um limite, por doador, equivalente a $2 \%$ do faturamento bruto do ano anterior à eleição.

Esse dispositivo, como já restou anotado linhas atrás, teve sua inconstitucionalidade proclamada pelo STF na ADI n. 4.650, sendo logo em seguida revogado, quando da vigência da Lei n. 13.165/2015.

Resta ainda, todavia, para as eleições a ocorrer doravante, a possibilidade do significativo uso de recursos privados nas campanhas eleitorais, provenientes de doações de pessoas físicas e do emprego de recursos próprios do candidato.

Considerado esse cenário de financiamento privado das campanhas eleitorais - associado à inexistência, ao menos até o momento, de quais- 
quer limites máximos genericamente fixados em lei para todas as eleições, para despesas de campanha -, o que se tem, na verdade, é a instalação de um quadro em que a influência do poder econômico pode acabar sendo decisiva para o sucesso de uma candidatura.

Certamente que esta influência restará diminuída com o afastamento das doações de campanhas realizadas por pessoas jurídicas, já noticiado. Sem embargo, poderá vir a ocorrer que os titulares do controle e até mesmo eventuais administradores melhor aquinhoados de pessoas jurídicas venham a ampliar as doações que façam na qualidade de pessoas jurídicas, ainda que limitadas ao teto de $10 \%$ (dez por cento) de seus rendimentos brutos do ano imediatamente anterior ao da eleição.

De resto, a possibilidade de uso de recursos próprios do candidato, limitados, inclusive, ao máximo de gastos de campanha que venha a ser fixado pelo TSE, observados parâmetros legalmente estabelecidos (e que, ao menos por enquanto, inexistem, como já se observou), permite o favorecimento, durante a disputa, daquele candidato que seja ele próprio melhor bafejado pela fortuna.

O que a Constituição pretendeu, ao dizer que a normalidade e a legitimidade das eleições não deveriam ser maculadas pela influência do poder econômico - entendida a palavra no sentido já anteriormente apresentado -, está agora, talvez, mais próximo, mas ainda longe de ser alcançado, levando em consideração o sistema legal de financiamento de campanhas eleitorais como permanece, hoje, em vigor, ainda amplamente centrado em recursos privados.

Não havendo limite legalmente traçado para despesas com as candidaturas, abrem-se as portas para a influência da maior abundância de recursos financeiros com que determinado partido ou determinado candidato possa contar.

Isso, por evidente, importa também em afronta ao princípio constitucional da isonomia, no que tange às candidaturas a um mesmo mandato eletivo. Candidato que dispuser de mais recursos econômicos e deles fizer uso eficiente poderá, em princípio, ter melhores oportunidades de sensibilizar os eleitores do que candidato cujo aporte de recursos for menor.

Em suma, o financiamento privado de campanhas eleitorais, como ainda disciplinado, hoje, entre nós, a um tempo permite que se instile -e de modo aberto, sem que sequer se possa falar em abuso - a influência do poder econômico nas eleições e que, justamente em virtude disso, se 
quebre o princípio da igualdade de todos os candidatos no pleito. Maiores chances, potencialmente, para os que consigam mobilizar maiores recursos financeiros.

O sistema legal disciplinador das eleições brasileiras coíbe o abuso do poder econômico, mas não Ihe interdita o uso. Abuso é uso para além do permitido, e para uso não há, ao menos, até agora, limite legalmente fixado no tocante ao máximo de gastos de campanha, embora restritas as doações de pessoas físicas (mas não o uso de recursos próprios do candidato, justamente pela ausência, até aqui, de um limite máximo legalmente estipulado).

Nas palavras de José Cretella Júnior acerca do $\S 9^{\circ}$ do art. 14 da Constituição:

A primeira finalidade da lei complementar que estabelecerá outros casos de inelegibilidade e os prazos de sua cessação é a de proteger a normalidade e a legitimidade das eleições contra a influência do poder econômico. Forças econômicas poderosas poderão atentar contra a normalidade e legitimidade de eleições concluídas, impugnando-Ihes a validade, em defesa de interesses de empresas. ${ }^{14}$

Ou, nas palavras de Fávila Ribeiro:

A luta contra o abuso é, portanto, menos restrita do que se possa supor, tendo de cobrir todos os flancos, escudando-se nos mananciais da ordem, seja para impedir as manifestações opressivas do poder com dano para a liberdade, seja também a não permitir que esta degenere com exorbitâncias possessivas, articulando situações discriminatórias que levam ao aniquilamento das reservas essenciais da igualdade, solapando as bases da justiça na convivência social e da equidade na participação política. ${ }^{15}$

Em verdade, não se cuida apenas de prevenir o abuso do poder. Tratase, mais que isso, de preservar a igualdade, proscrevendo o próprio uso do poder econômico nas eleições.

\section{O financiamento público de campanhas eleitorais, como poten- cial solução para o problema de afronta ao texto constitucional, antes anunciado}

O financiamento público das campanhas eleitorais, a despeito das dificuldades de disciplinamento e de operacionalização que possa acarretar, serve como solução ao problema constitucional que se acaba de ferir. 
O financiamento privado de campanhas eleitorais permite que a maior abundância de recursos econômicos possa influir no resultado das eleições, o que decididamente o $\S 9^{\circ}$ do art. 14 da Constituição não deseja. Máxime quando tal financiamento privado acontece em ambiente no qual nem sequer existe, ao menos por enquanto, previsão legal de limite máximo de gastos de campanha, cabendo exclusivamente aos próprios partidos, a cada eleição e em vista das diversas candidaturas, a indicação dos seus próprios limites máximos de gastos.

Além da violação ao pretendido pelo § $9^{\circ}$ do art. 14 da Constituição, segundo já se viu, esse sistema de financiamento de campanhas eleitorais malfere o princípio constitucional da isonomia, permitindo, em tese, melhores oportunidades de obtenção de votos àqueles que tenham ao seu dispor maior volume de recursos de campanha, em detrimento daqueles que possam servir-se apenas de cifras mais modestas. Não teria nenhum cabimento cogitar da simples supressão das campanhas eleitorais. Tal seria virtualmente negar ao candidato o direito de comunicar-se com o eleitor e negar a este último o mínimo de condições para informar-se acerca do pensamento de quantos concorrem ao pleito, de sorte a munir-se de critérios que lhe permitam optar no momento do voto.

As campanhas eleitorais são inerentes à democracia representativa. Sem elas, veda-se a possibilidade do intercâmbio entre candidatos, partidos e eleitores, embora esse intercâmbio esteja cada vez mais convertido em via de mão única, por força do peso específico da propaganda via rádio e televisão, que permite aos candidatos dizerem o que pensam, embora não propiciem caminhos para que também o eleitor se faça por eles ouvir. De qualquer sorte, essa deficiência na comunicação, que transforma o potencial diálogo em monólogo, ainda assim jamais poderia ser havida como justificativa capaz de fazer supor dispensável a campanha eleitoral.

Necessária que se mostra a campanha, evidente também que, para empreendê-la, há necessidade de que os recursos financeiros para tanto imprescindíveis estejam disponíveis. Se a campanha é premissa da democracia representativa, pois significa a oportunidade para que partidos e candidatos entrem em contato com o eleitorado e Ihe exponham seu pensamento, de sorte a sensibilizá-lo para conferir-lhes seu voto, também é inegável que a realização dessa comunicação não prescinde de recursos econômicos. 
Inviável cogitar, portanto, da supressão das campanhas. O que se afigura necessário é encontrar mecanismos para o custeio, que a um tempo respeitem a pretensão constitucional de afastar a influência (e não simplesmente o abuso) do poder econômico do âmbito das campanhas e, com isso, propiciar equalização dos candidatos nessa perspectiva de comunicação com o eleitorado.

Se o financiamento privado de campanhas eleitorais, associado à inexistência de qualquer limite estipulado previamente em lei para os gastos de campanha, não tende a esse objetivo, a alternativa disponível consiste no financiamento público das campanhas.

Certo que se poderia objetar quanto à suficiência do estabelecimento de limites legais, ainda que elevados, para os gastos de campanha eleitoral, mantido o seu custeio com recursos de origem particular.

Isso, porém, não resolveria nem o problema da potencial influência do poder econômico no resultado das eleições, nem o da quebra da isonomia entre os candidatos, da perspectiva das disponibilidades de recursos. Não resolveria o primeiro problema porque, previsto limite suficiente (e provavelmente elevado) para os gastos de campanhas eleitorais, ainda assim a origem privada dos recursos empregados no pagamento desses gastos permitiria a influência do poder econômico. Nem resolveria o problema de igualdade entre os candidatos, considerando justamente que haveria aqueles com maior capacidade de mobilização de recursos financeiros (mesmo existindo um limite máximo legalmente previsto), o que sempre manteria a possibilidade de colocá-los em situação de vantagem em face daqueles que somente conseguem alavancar recursos de menor monta.

Vai daí ser o financiamento público das campanhas eleitorais, em limites suficientes para fazer face a gastos com campanha eleitoral com qualidade e amplitude para alcançar todo o corpo eleitoral e também para servir como fonte de informação e, assim, de convencimento, a solução para a temática exposta.

\section{Alguns acenos da legislação, no sentido do financiamento públi- co, embora ainda não (totalmente) implantado}

Em que pese ser ainda o financiamento público de campanhas eleitorais tema de projetos de lei em tramitação no Congresso Nacional, a própria legislação, já em vigor, acena no sentido da preferência por esse sistema de financiamento. 
Nesse sentido, o art. 79 da Lei n. 9.504/1997, que contém normas sobre as eleições, afirma que: "O financiamento das campanhas eleitorais com recursos públicos será disciplinado em lei específica." Já se afigurava o propósito, portanto, desde quando aprovada aquela lei, de que as despesas com campanhas eleitorais fossem custeadas com recursos públicos.

Sintomático, nesse sentido, é também que o art. 81 da mesma lei no qual são autorizadas doações e contribuições de pessoas jurídicas para campanhas eleitorais -, havido por inconstitucional e hoje expressamente revogado, estivesse incluído entre as disposições daquela lei, por ela própria denominadas de transitórias.

As regras do caput e dos $\S \S 1^{\circ}$ e $2^{\circ}$ do art. 81 da Lei n. 9.504/1997 em si mesmas, do modo como se achava redigida a do caput e ainda se acham as dos parágrafos (não revogados para evitar desaparecimento da possibilidade de sancionamento de quem, antes da declaração de inconstitucionalidade e especialmente da revogação expressa, houvesse incidido em ilicitudes relativas a doações de pessoas jurídicas), nada tinham de transitórias. Seu conteúdo era de cunho permanente, podendo ser aplicadas enquanto não ocorresse revogação (ou declaração de inconstitucionalidade).

A sua inclusão entre as disposições transitórias da lei, todavia, deve ser entendida em conjunto com o art. 79 do texto legislativo em questão. Dos dois dispositivos em conjunto podia-se extrair a seguinte conclusão: o pretendido, para o futuro, era (e continua sendo) o financiamento público, mas, enquanto este não é disciplinado, seriam admitidas doações de pessoas jurídicas, além daquelas de pessoas físicas e do emprego de recursos próprios do candidato na sua campanha, como a seu turno disciplinado pelo art. $23, \S \S 1^{\circ}$ e $1^{\circ}$-A (este último acrescentado pela Lei $n$. 13.165/2015), da Lei n. 9.504/1997. Naturalmente que, a sobrevir financiamento público, também a possibilidade de custeio de despesas de campanha com doações recebidas de pessoas físicas e com recursos próprios do candidato haverá que ser suprimida, ao menos no âmbito das campanhas cujo financiamento público venha a ser assegurado.

A par desse aceno legislativo, cabe relembrar também que, para custeio de despesas com campanhas eleitorais, é lícito aos partidos servirem-se de recursos do Fundo Partidário, criado por intermédio do art. 38 da Lei n. 9.096, de 19 de setembro de 1995, conhecida como Lei dos Partidos Políticos. 
Entre os vários recursos que integram referido fundo, incluem-se dotações orçamentárias da União. Certo que, depois de transferidos ao Fundo Partidário e principalmente depois que os recursos do fundo são rateados e entregues aos partidos pelo Tribunal Superior Eleitoral, na conformidade do art. 41 da mesma lei, deixam de ser públicos para se transformarem em recursos privados, na medida em que os partidos são pessoas jurídicas de Direito Privado. Mesmo assim, porém, cabe reconhecer que, sendo de origem pública uma parcela (e bastante significativa) dos recursos integrantes do fundo, ao menos em parte o financiamento das campanhas eleitorais já pode contar com suporte de dinheiro de origem pública. O mesmo raciocínio vale também para multas e penalidades pecuniárias aplicadas pela Justiça Eleitoral, que também integram o Fundo Partidário.

\section{Breve elenco de conclusões}

Ao cabo dessas ponderações mostra-se possível alinhavar algumas conclusões:

I - o § $9^{\circ}$ do art. 14 da Constituição autoriza a previsão, por lei complementar, de outras causas de inelegibilidade, além daquelas inscritas no próprio texto constitucional, desde que sejam aptas à preservação, dentre outros valores, da legitimidade e da normalidade das eleições contra a influência do poder econômico;

II - por influência do poder econômico se haverá de entender a potencialidade da definição do resultado das eleições em face da maior ou menor capacidade do candidato ou do partido para obter recursos financeiros a serem empregados no custeio das despesas com a sua campanha eleitoral;

III - influência do poder econômico não se confunde, pois, com abuso do poder econômico, na medida em que este significa o uso desse poder para além do permitido; o texto constitucional, todavia, procura afastar não somente o abuso, como também toda possibilidade da própria influência do poder econômico no resultado das eleições;

IV - o modelo de financiamento privado de campanhas eleitorais hoje vigente no Brasil, mesmo depois do desaparecimento da possibilidade de doações de pessoas jurídicas, mas persistindo aquelas de pessoas físicas e o uso de recursos próprios do candidato, aliado à inexistência, ao menos por enquanto, de limite legal para gastos de campanha, permite que a influência do poder econômico se instile nas campanhas eleitorais, contrariando a pretensão do texto constitucional de que tal influência não ocorra; 
$V$ - essa possibilidade de influência do poder econômico, via financiamento privado de campanhas eleitorais, máxime quando não haja limites de gastos previamente fixados por lei, permite a quebra da igualdade entre os candidatos ao pleito, com violação ao princípio constitucional da isonomia, nesta particular perspectiva;

$\mathrm{VI}$ - campanhas eleitorais devem acontecer, visto que inerentes ao mecanismo da democracia representativa, por serem o instrumento para que partidos e candidatos apresentem aos eleitores seu pensamento e suas propostas de trabalho, fornecendo-lhes parâmetros para decisão no momento do voto; por isso mesmo, inviável cogitar pura e simplesmente da supressão das campanhas eleitorais;

$\mathrm{VII}$ - campanhas eleitorais envolvem gastos de recursos financeiros, de tal sorte que se mostra indispensável prever a respectiva fonte;

VIII - a simples fixação por lei de limites máximos de gastos de campanhas eleitorais não se mostra eficaz para afastar a potencialidade da influência do poder econômico nas eleições, nem permite o estabelecimento da igualdade entre os candidatos, uma vez que sempre persistirá a desigualdade nas possibilidades de obtenção de recursos de campanha;

IX - em decorrência, o financiamento público de campanhas eleitorais, com recursos em quantia suficiente a uma campanha eleitoral potencialmente eficaz, é o mecanismo que se mostra apto a, de um lado, afastar a influência do poder econômico sobre a normalidade e a legitimidade das eleições e, de outro, equalizar os candidatos, na perspectiva dos recursos disponíveis para suas campanhas.

Certamente que muitos aspectos existem envolvidos no assunto. Não é propósito deste estudo modesto, porém, nem seria compatível com as capacidades de seu autor, exaurir a discussão de todos eles. O que aqui se pretendeu foi apenas fornecer aquela que parece ser a justificativa constitucional para a implantação do financiamento público de campanhas eleitorais no Brasil.

\section{Referências}

CAMPANHOLE, Adriano; CAMPANHOLE, Hilton Lobo. Todas as Constituições do Brasil: compilação dos textos, notas, revisão e índices. 2. ed. São Paulo: Atlas, 1976.

CÂNDIDO, Joel José. Inelegibilidades no Direito brasileiro. Bauru, SP: Edipro, 1999. 
CRETELLA JÚNIOR, José. Comentários à Constituição Federal de 1988. v. 2. Arts. 5 (LXVIII a LXXVIII) a 17. Rio de Janeiro: Forense Universitária, 1989.

DECOMAIN, Pedro Roberto. Elegibilidade e inelegibilidades. 2. ed. São Paulo: Dialética, 2004.

FERREIRA FILHO, Manoel Gonçalves. Comentários à Constituição brasileira de 1988. v. 1. Arts. $1^{\circ}$ a 43. São Paulo: Saraiva, 1990.

. Comentários à Constituição brasileira. v. 3. Arts. 130 a 210. 2. ed. São Paulo: Saraiva, 1977.

JACQUES, Paulino. Curso de Direito Constitucional. 8. ed. Rio de Janeiro: Forense, 1977.

MENDES, Antônio Carlos. Aspectos da ação de impugnação de mandato eletivo. In: VELLOSO, Carlos Mário da Silva; ROCHA, Cármen Lúcia Antunes. Direito Eleitoral. Belo Horizonte: Del Rey, 1996. p. 331-342.

NIESS, Pedro Henrique Távora. Ação de impugnação de mandato eletivo. Bauru, SP: Edipro, 1996.

RIBEIRO, Fávila. Abuso de poder no Direito Eleitoral. 3. ed. Rio de Janeiro: Forense, 1998.

VAZ, Orlando. Impugnação de mandato eletivo. In: VELLOSO, Carlos Mário da Silva; ROCHA, Cármen Lúcia Antunes. Direito Eleitoral. Belo Horizonte: Del Rey, 1996. p. 343-367.

\section{Notas}

${ }^{1}$ Artigo publicado na revista RESENHA ELEITORAL - Nova Série, v. 13, 2006. Atualizado e revisado em outubro de 2015.

${ }^{2}$ Promotor de Justiça em Santa Catarina. Mestre em Ciência Jurídica pela Universidade do Vale do Itajaí (Univali). Professor de Direito Eleitoral na Universidade do Contestado (UnC), campus Mafra/SC. Professor de Direito Eleitoral na Escola do Ministério Público de Santa Catarina. Professor em Curso de Especialização em Direito Eleitoral promovido pela Univali e pelo TRESC.

${ }^{3}$ FERREIRA FILHO, Manoel Gonçalves. Comentários à Constituição brasileira de 1988. v. 1. Arts. $1^{\circ}$ a 43. São Paulo: Saraiva, 1990. p. 13. [Os negritos constam no original.]

${ }^{4}$ CAMPANHOLE, Adriano; CAMPANHOLE, Hilton Lobo. Todas as Constituições do Brasil: compilação dos textos, notas, revisão e índices. 2. ed. São Paulo: Atlas, 1976. p. 125.

${ }^{5}$ A propósito da Emenda Constitucional n. 1/1969, vale lembrar a observação 
de Paulino Jacques, para quem, por haver ela introduzido mais de duzentas alterações na Constituição de 1967, que continha apenas 189 artigos: "importou, pragmaticamente, na outorga de nova Carta Política, denominada 'Constituição da República Federativa do Brasil'” (JACQUES, Paulino. Curso de Direito Constitucional. 8. ed. Rio de Janeiro: Forense, 1977. p. 156).

${ }^{6}$ CAMPANHOLE; CAMPANHOLE, op. cit., p. 54.

${ }^{7}$ FERREIRA FILHO, Manoel Gonçalves. Comentários à Constituição brasileira. v. 3. Arts. 130 a 210. 2. ed. São Paulo: Saraiva, 1977. p. 63.

${ }^{8}$ Lei Complementar n. 64/1990: "Art. $1^{\circ}$ São inelegíveis: [...] II - para Presidente e Vice-Presidente da República: [...] e) os que, até 6 (seis) meses antes da eleição, tenham exercido cargo ou função de direção, administração ou representação nas empresas de que tratam os arts. $3^{\circ}$ e $5^{\circ}$ da Lei n. 4.137 , de 10 de setembro de 1962, quando, pelo âmbito e natureza de suas atividades, possam tais empresas influir na economia nacional; f) os que, detendo o controle de empresas ou grupos de empresas que atuem no Brasil, nas condições monopolísticas previstas no parágrafo único do art. $5^{\circ}$ da lei citada na alínea anterior, não apresentarem à Justiça Eleitoral, até 6 (seis) meses antes do pleito, a prova de que fizeram cessar o abuso apurado, do poder econômico, ou de que transferiram, por força regular, o controle de referidas empresas ou grupos de empresas; [...] h) os que, até 6 (seis) meses depois de afastados das funções, tenham exercido cargo de Presidente, Diretor ou Superintendente de sociedades com objetivos exclusivos de operações financeiras e façam publicamente apelo à poupança e ao crédito, inclusive através de cooperativas e da empresa ou estabelecimentos que gozem, sob qualquer forma, de vantagens asseguradas pelo Poder Público, salvo se decorrentes de contratos que obedeçam a cláusulas uniformes; [...]". As referências à Lei n. 4.137/1962 devem ser hoje substituídas pela referência aos dispositivos equivalentes constantes na Lei n. 8.884/1994.

${ }^{9}$ NIESS, Pedro Henrique Távora. Ação de impugnação de mandato eletivo. Bauru, SP: Edipro, 1996. p. 24.

${ }^{10}$ DECOMAIN, Pedro Roberto. Elegibilidade e inelegibilidades. 2. ed. São Paulo: Dialética, 2004. p. 163.

${ }^{11}$ CÂNDIDO, Joel José. Inelegibilidades no Direito brasileiro. Bauru, SP: Edipro, 1999. p. 337.

${ }^{12}$ VAZ, Orlando. Impugnação de mandato eletivo. In: VELLOSO, Carlos Mário da Silva; ROCHA, Cármen Lúcia Antunes. Direito Eleitoral. Belo Horizonte: Del Rey, 1996. p. 349.

${ }^{13}$ MENDES, Antônio Carlos. Aspectos da ação de impugnação de mandato eletivo. In: VELLOSO, Carlos Mário da Silva; ROCHA, Cármen Lúcia Antunes. Direito Eleitoral. Belo Horizonte: Del Rey, 1996. p. 338-339. 
${ }^{14}$ CRETELLA JÚNIOR, José. Comentários à Constituição Federal de 1988. v. 2. Arts. $5^{\circ}$ (LXVIII a LXXVIII) a 17. Rio de Janeiro: Forense Universitária, 1989. p. 1108-1109.

${ }^{15}$ RIBEIRO, Fávila. Abuso de poder no Direito Eleitoral. 3. ed. Rio de Janeiro: Forense, 1998. p. 21-22. 